\title{
Computer verification of the production cycle implemented on swiss-type lathe
}

\author{
Komputerowa weryfikacja cyklu produkcyjnego \\ realizowanego na automacie wzdłużnym
}

\section{PIOTR SIKORA \\ MARCIN SOBIEGRAJ ANDRZEJ ZABORSKI *}

The study presents the possibility of using CAD/CAM systems for computer simulation of the process of making the detail on a numeric processing machine. The paper describes an exemplary process of verification of the element's creation using SD EDITOR software and the actual creation of the product on the Star ECAS-20 longitudinal automatic machine based on the verified NC code.

KEYWORDS: computer-aided production preparation, CAD/CAM systems

Production preparation processes in the machine industry are increasingly being implemented using advanced CAD and CADICAM systems [1,6]. They include both the design and construction stage of product preparation as well as computer-aided production [3, 4].

An integral part of computer-aided production is the stage of technological preparation of the production of products. At this stage, more and more often CAD/CAM systems are used, enabling the computer-generated NC control code generation for the selected machine tool and supporting the selection of the proper machining parameters [3,5]. Much less industrial use are found in the machining simulators, which do not automatically generate the machine control code, but only serve to verify the code developed by the programmer.

The development of numerically controlled machines used to process increasingly complex details and the use of increasingly specialized tool holders and tools require developers to develop a spatial imagination. This problem was noticed by software producers who prepared the application for machining simulation, which allows to verify in the virtual environment the NC code written manually by the programmer.

It enables the preparation of workmanship, starting from the choice of the machine tool, through the development of individual technological steps, the selection of optimal tools, and verification of the machining parameters. Virtual

\footnotetext{
* Mgr Piotr Sikora (psikora@wimii.pcz.pl), mgr inż. Marcin Sobiegraj (msobiegraj@wimii.pcz.pl), dr hab. inż. Andrzej Zaborski prof. PCz (zaborski@itm.pcz.czest.pl) - Instytut Technologii Mechanicznych Politechniki Częstochowskiej
}

machining verification allows for safe and quick detection and correction of any errors occurring at the stage of developing and editing the NC control code $[3,4]$.

The study uses the simulation program SD-Editor from Star Micronics Co. LTD [2].

\section{Preparation of the machining process using a computer}

In the presented machining example, a detail was selected to simulate the process (fig. 1) made of copper in the M1E grade. The correct implementation of the treatment of this element involves the use of a large number of tools, with some treatments requiring simultaneous machining with two cutters and the engagement of two lathe tools at the same time. Thus, an increased risk of collision between the tool and the material being processed appears.

The computer simulation process allows detection and elimination of this non-safety with high probability. The solid model of the presented detail and the actual detail obtained as a result of the completed machining process are presented in fig. 1. a)

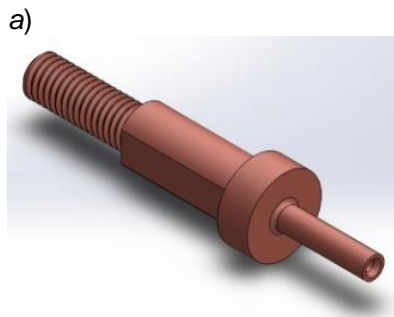

b)

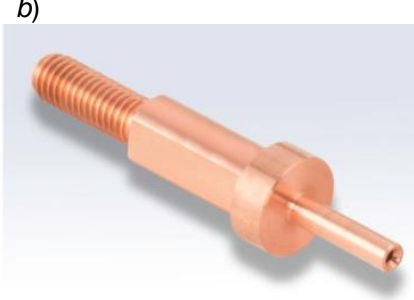

Fig. 1. Detail being made: a) the virtual model, $b$ ) the actual detail obtained as a result of processing

The work in the SD-Editor begins with the selection of the machine tool in the "Machine Setup" dialog. The selection of the guide bush type is then made and the data regarding the processed starting material is entered. In the presented example, it was a bar fed through the spindle to the machining space by means of a bar feeder, which allows using rods with a diameter of $\emptyset 3$ to $\emptyset 20 \mathrm{~mm}$ and lengths up to $3000 \mathrm{~mm}$ for machining. In the bar feeder settings it is possible to enter such parameters as: material exit 
diameter, element length, start position in the $Z$ axis and the position from which the spindle starts to work.

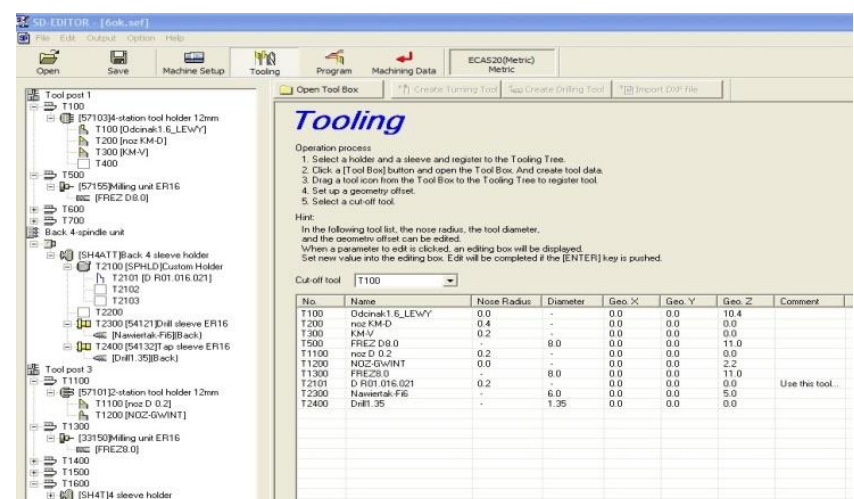

Fig. 2. "Tooling" dialog window for defining the tools used

At the next stage, going to the "Tooling" tab allows to choose a tool holder and cutting tools for machining a workpiece (fig. 2). The introduction of this data enables the execution of the machining simulation process to detect possible collisions and eliminate errors appearing in the machine code.

The floating tool tree, located on the left side of the screen, allows you to select the position of the tool marked with the tool holder number (labeled with the capital letter "T"). Next, the type of tool holder that will be mounted in the respective slot is selected.

The next step is to select the tool working in the selected frame and describe it using its geometry. The right side of the dialog box allows you to review tabbed filled tool sockets.

The correct definition of the selected numerically controlled machine tool and the tools involved in the processing together with the frames assigned to them allows you to enter the stage of entering into the simulator a control program edited manually using G-codes. It is also possible to read and simulate verification previously written and archived in the NC program file.

In the example, the workpiece simulation was carried out using the SD-Editor program configured to use the Star ECAS-20 longitudinal automatic machine, equipped with a bar feeder. To perform this detail, it was necessary to use both the main spindle and the machine tool spindle.

On the main spindle, tools for workpiece machining on the thread side were installed, i.e. two simultaneous DCMT type turning tools (with a corner radius of $0.4 \mathrm{~mm}$ and 0.2 $\mathrm{mm}$ ), mounted in tool bars controlled by two channels enabling their independent operation. The next tools used were two cutters. They were also controlled by two separate control channels. The cut was used to make a metric thread and knife cutter. On the counter-spindle, we used paws for receiving details and three tools: a drill with a diameter of $\varnothing 1,35 \mathrm{~mm}$, a drill bit and a frame for a DCMT type turning tool with a corner with a rounding radius of $0.2 \mathrm{~mm}$. The program written by the programmer was imported to the simulator.

After arming the virtual machine with the tools needed to make the part and load the NC program subject to simulation verification, it was possible to simulate all machining operations provided for in this technological operation.

As the first one is carried out the transfusion process to the given size with the use of two knives simultaneously (fig. 3). Then threading of the element is carried out by means of a special die intended for processing copper.

After these machining operations, the technological undercut is made according to the construction requirements of the detail. Another verified operation is simultaneous milling of the side planes of the element using two-channel control (fig. 4). Then the detail is prepared for interception.

The spindle drive of the interceptor takes place, catching the detail and cutting it off with a knife cutter.

After the counter-spindle leaves the working position, the remaining parts are machined. As the first one after drilling the drill is drilled, and then the hole $\varnothing 1,35 \mathrm{~mm}$ is machined using the HSS drill with a specially prepared geometry adapted to the processing of copper. The final stage of the machining carried out before handing the element to the foot is to roll the diameter into the given dimension. The rolling treatment on the handle is shown in fig. 5 .

The presented process simulation process implemented in the program in the SD-Editor program was aimed at detecting possible collisions of processing tools and errors in the control code.

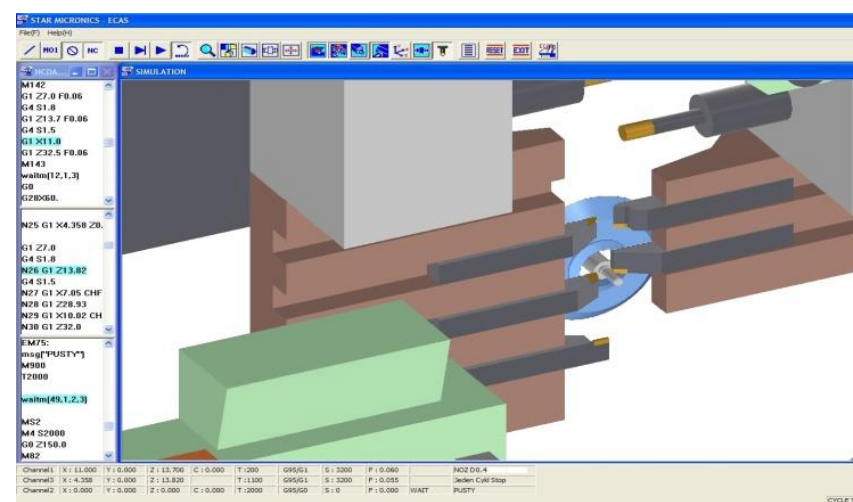

Fig. 3. Simulation of rolling with the simultaneous use of two knives

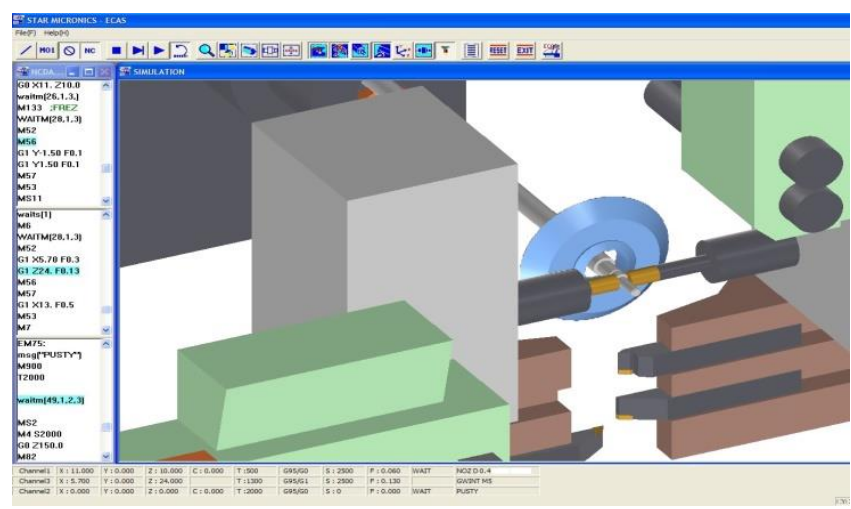

Fig. 4. Performing simultaneous milling of side planes

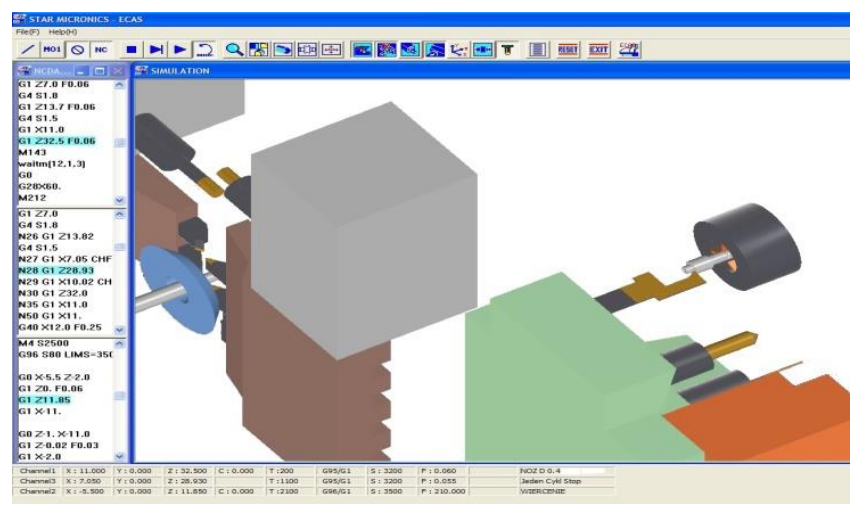

Fig. 5. Turning the element on the chuck

\section{Implementation of the verified machining process on} a longitudinal machine

The computer-verified machining process was carried out on a Star ECAS-20 longitudinal automatic machine, numerically controlled (fig. 6).

The machine is equipped with Siemens - Yaskawa control system and bar feeder, which enable continuous 
work, without the need to load material into the main spindle [7]. On this machine you can make details from a rod with diameters from $\varnothing 3 \mathrm{~mm}$ to $\varnothing 20 \mathrm{~mm}$. It enables: turning, milling, drilling, boring, threading and knurling.

out on the Star ECAS-20 longitudinal automat with Siemens-Yaskawa control.

A virtual analysis of tool passages and rapid machine movements to detect collisions was performed as well as optimization of tool paths for the workpiece. Simulation of

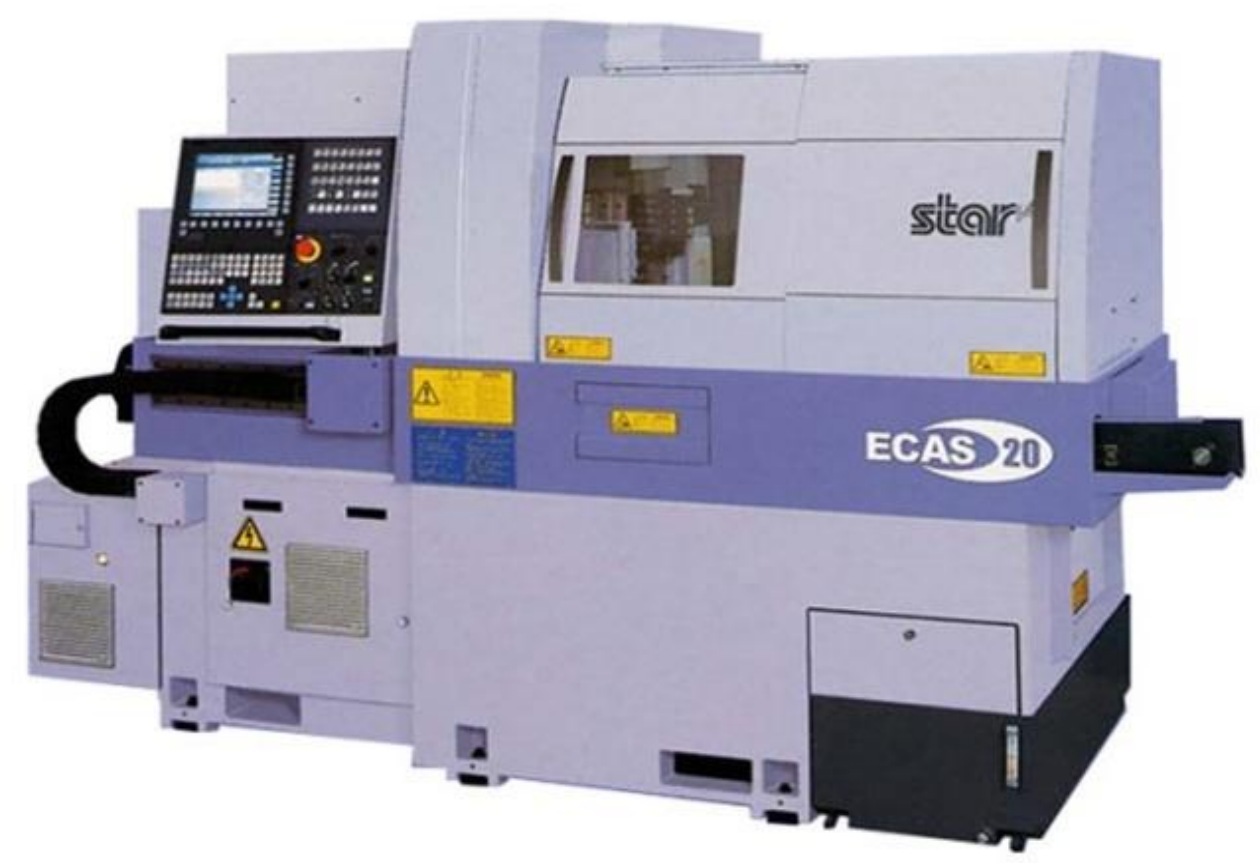
machining allowed for mapping of the actual machining process of the part in the machine space. It was necessary to carry out the processing of such a complicated detail that required the work of several tools at the same time, carried out in order to speed up serial production. The simulation enabled detection and elimination of any errors occurring in the threechannel NC control program written in manual mode by the operator.

Virtual code verification is particularly important in the analysis of the possibility of collision situations. The industrial use of machining simulators realized on numerically controlled machine tools is becoming

Fig. 6. Star ECAS-20 longitudinal automatic machine [7]

The machine is equipped with 10 numerically controlled axes, including two $C$ axes driven by $2.2 \mathrm{~kW}$ electric motors, which allows reaching $10,000 \mathrm{rpm}$ in continuous operation. The machine also has driven tools with a power of $0.75 \mathrm{~kW}$, which allows you to distribute cutters and drills up to 8,000 $\mathrm{rpm}$. This machine tool can work simultaneously with two turning knives on the main spindle, thanks to the $Z 3$ axis on the right tool bar and a special three-channel control.

A Star ECAS-20 machine was used, equipped with APJ Sikora in Częstochowa, which deals with precision machining. The machining process previously carried out using the SD-Editor was implemented on the actual machine tool and put into production (fig. 7).

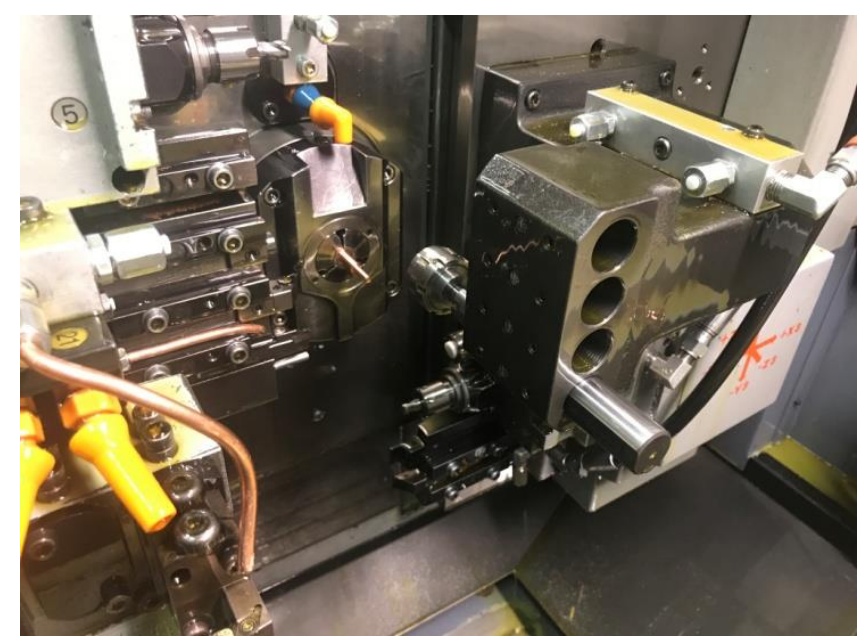

Fig. 7. Working space of the machine tool with the workpiece

\section{Conclusions}

The paper presents the possibilities of using one of the machining simulators - the SD-Editor program for virtual verification of the technological processing process carried an interesting complement to the offer of increasingly popular CAD/CAM systems, which automatically generate $\mathrm{NC}$ control codes.

\section{REFERENCES}

1. Dassault Systemes SolidWorks Corporation. „Podstawy SolidWorks". Waltham, MA 02451 USA.

2. Star Micronics Co. Ltd. "SD-Editor No.2001E Operation Manual". 3. Tagowski M., Zaborski A. „Przygotowanie produkcji wyrobów przy zastosowaniu systemów CAD i CAD/CAM". Mechanik. 88, 7 (2015): pp. 568/849-856 (CD).

4. Tagowski M., Zaborski A. „Przygotowanie produkcji wyrobów na OSN przy zastosowaniu systemów CAD/CAM". Mechanik. 89, 7 (2016): pp. 846-847.

5. Tagowski M., Zaborski A. „Komputerowo wspomagane przygotowanie wykonania oprzyrządowania technologicznego przy wykorzystaniu systemów CAD/CAM". Mechanik. 90, 7 (2017): pp. 578-580.

6. Zaborski A., Tubielewicz K. „Zastosowanie systemów CAD/CAM do komputerowo wspomaganego przygotowania produkcji". Mechanik. 77, 8-9 (2004): pp. 588-591.

7. http://starcnc.com/product/ecas-20/.

Translation of scientific articles, their computer composition and publishing them on the website www.mechanik.media.pl by original articles in Polish is a task financed from the funds of the Ministry of Science and Higher Education designated for dissemination of science. 